\title{
骨組構造に関する有限要素法の計算法的側面 COMPUTATIONAL ASPECTS OF FINITE ELEMENT METHOD FOR A FRAME STRUCTURE
}

\author{
上原 七 司* \\ By Shichishi Uehara
}

\section{1.はしがき}

有限要素法は一般には変分法に基礎ゔけられている。 一般に連続体が有限の要素に分割され，それぞれの要素 のなかで displacement field または stress field, ある いはそれの両者が仮定されて，変分法が適用される。そ の結果は節点における一般変位あるいは一般応力に関す る連立方程式となり，これを解いて近似解がえられる。 実際の適用においては, compatible model, equilibrium model, hybrid method, mixed method などが提出さ れ応用されている1)。

これらの方法は特に連続体に関連して研究されてい る。連続体では微分方程式を直接的に扱うことは，一般 にはほとんど不可能であろう。

この論文では, 変断面の部材からなる骨組構造の間題 (静力学的問題, 振動の問題, 座屈の問題など) を解く ことを念頭においており, 変分法の原理を直接的には適 用せず，微分方程式を扱って有限要素法の手法をとり入 れることを試みる。それで最初に述べた一般的な立場を 仮に（I）の立場と呼び，ここで試みる立場を（II）の 立場ということにする。

この試みの目的は次の点にある。

（i）部材の物理定数と変形関数とのあいだの関係を 知ること。

(ii) 変位, 応力, 固有振動数などの計算結果の近似 性を評価する簡単な関係式が欲しいこと。

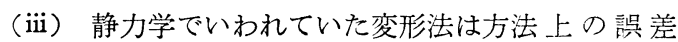
(ここでは discretization error) を含まない形式にな っているが，この方式との関係をみること，このことは (ii) に役立つ。

（II）の立場では微分方程式のままで近似解を扱う次 の定理が吕土台とされる。これを仮に（II）の定理とい

\footnotetext{
* 正会員 日本建設コンサルタント（株）開発室
}

う。

「微分方程式：

$$
\frac{d \boldsymbol{y}}{d x}-\boldsymbol{A}(x) \boldsymbol{y}=\boldsymbol{g}(\boldsymbol{y}, \epsilon)
$$

の解は, 十分小さい $\epsilon$ に対して， $\epsilon=0$ の解に近似して いる」 $\rfloor^{6)}$ 。どの程度小さければよいかは，方程式の型依 存する。本論では曲げ変形の問題を扱う。

\section{2. 曲げ変形}

長さ $l$ のエレメントをとり，曲げ剛性 $E I$ と単位長 あたり重量 $w(m=w / g)$ は連続的に分布しているもの とする。長さの方向に $x$ 軸，たわみの方向に $v$ 軸をと り， $x$ 軸から $v$ 軸への回転を $\theta$ と方る。 $x=0$ を 1 端, $x=l$ を 2 端と呼び, この点の值はサフィックスをつけ て表示する。EI および $m$ は $x$ の滑らかな関数と仮定 されているわけである。

$v$ 方向の分布力密度を $h=h(x)$ とおき, 曲げモーメ ントを $M$, せん断力を $Q$ とすれば,

$$
\begin{aligned}
& M=-E I \frac{d^{2} v}{d x^{2}}, Q=\frac{d M}{d x}, \\
& \frac{d Q}{d x}=\frac{d^{2} M}{d x^{2}}=-h \quad \ldots \ldots \ldots . . .
\end{aligned}
$$

となる。

式 (2.1) の第 3 式を積分し, 両端に抢ける $M$ の值 で表わすと, 次の形で $M$ を表わすことができる：

$$
\begin{aligned}
& M=g(x)+\frac{M_{1}(l-x)+M_{2} x}{l}, \\
& g(x) \equiv \frac{l-x}{l} \int_{0}^{x} z h d z+\frac{x}{l} \int_{x}^{l}(l-z) h d z .
\end{aligned}
$$

式 (2.2)の $M$ を式 (2.1) の第1式に代入して積分し, 両端における $\theta$ の值を求出する：

$$
\theta_{1}=\frac{v_{2}-v_{1}}{l}+\int_{0}^{l} \frac{(l-x)^{2}}{E I l^{2}} d x \cdot M_{1}
$$




$$
\begin{aligned}
& +\int_{0}^{l} \frac{(l-x) x}{E I l^{2}} d x \cdot M_{2}+\mathfrak{U}, \\
& \theta_{2}=\frac{v_{2}-v_{1}}{l}-\int_{0}^{l} \frac{(l-x) x}{E I l^{2}} d x \cdot M_{1} \\
& -\int_{0}^{l} \frac{x^{2}}{E I l^{2}} d x \cdot M_{2}-\mathfrak{B}, \\
& \mathfrak{A} \equiv \int_{0}^{l} \frac{l-x}{E I l} g(x) d x, \\
& \mathfrak{B} \equiv \int_{0}^{l} \frac{x}{E I l} g(x) d x .
\end{aligned}
$$

他方, 式 (2.2) を微分してせん断力の両端における 值を求めると, 次の形で表わされる：

$$
\begin{aligned}
Q_{1} & =\frac{M_{2}-M_{1}}{l}+હ, Q_{2}=\frac{M_{2}-M_{1}}{l}+\mathfrak{D}, \\
\mathfrak{S} & \equiv \int_{0}^{l} \frac{l-x}{l} h(x) d x, \\
\mathfrak{D} & \equiv-\int_{0}^{l} \frac{x}{l} h(x) d x . \ldots \ldots \ldots \ldots \ldots \ldots \ldots \ldots \ldots \ldots \ldots \ldots
\end{aligned}
$$

式 (2.3) および式 (2.4) から， $M_{1}, M_{2}, Q_{1}, Q_{2}$ を， $v_{1}, v_{2}, \theta_{1}, \theta_{2}$ およボ $\mathfrak{A}, \mathfrak{B}, \mathfrak{E}, \mathfrak{D}$ の関数として表わした ものが, 静力学の変形法である。 $\mathfrak{A}, \mathfrak{B}, \mathfrak{E}, \mathfrak{D}$ はいわゆる 荷重項である。いくつかの断面定数を定義すると，

$$
\begin{aligned}
& \alpha=\int_{0}^{l} \frac{(l-x)^{2}}{E I l^{2}} d x, \beta=\int_{0}^{l} \frac{x(l-x)}{E I l^{2}} d x, \\
& \gamma=\int_{0}^{l} \frac{x^{2}}{E I l^{2}} d x, \\
& \bar{\alpha}=\frac{\gamma}{\Delta}, \quad \bar{\beta}=-\frac{\beta}{\Delta}, \bar{\gamma}=\frac{\alpha}{\Delta}, \Delta \equiv \alpha \gamma-\beta^{2}
\end{aligned}
$$

次の関係式がえられる：

$$
\begin{aligned}
M_{1}= & \bar{\alpha} \theta_{1}-\bar{\beta} \theta_{2}-\frac{\bar{\alpha}-\bar{\rho}}{l}\left(v_{2}-v_{1}\right)-\bar{\alpha} \mathfrak{X}-\bar{\rho} \mathfrak{B}, \\
M_{2}= & \bar{\beta} \theta_{1}-\bar{\gamma} \theta_{2}-\frac{\bar{\beta}-\bar{\gamma}}{l}\left(v_{2}-v_{1}\right)-\bar{\beta} \mathfrak{A}-\bar{\gamma} \mathfrak{B}, \\
Q_{1}= & \frac{\bar{\beta}-\bar{\alpha}}{l} \theta_{1}-\frac{\bar{\alpha}-\bar{\beta}}{l} \theta_{2}+\frac{\bar{\alpha}-2 \bar{\beta}+\bar{\gamma}}{l^{2}}\left(v_{2}-v_{1}\right) \\
& -\frac{\bar{\rho}-\bar{\alpha}}{l} \mathfrak{U}-\frac{\bar{\gamma}-\bar{\beta}}{l} \mathfrak{B}+\mathfrak{C}, \\
Q_{2}= & \frac{\bar{\beta}-\bar{\alpha}}{l} \theta_{1}-\frac{\bar{\gamma}-\bar{\beta}}{l} \theta_{2}+\frac{\bar{\alpha}-2 \bar{\beta}+\bar{\gamma}}{l^{2}}\left(v_{2}-v_{1}\right) \\
& -\frac{\bar{\beta}-\bar{\alpha}}{l} \mathfrak{A}-\frac{\bar{\gamma}-\bar{\beta}}{l} \mathfrak{B}+\mathfrak{D} . \cdots \cdots \cdots \cdots \cdot(2.6)
\end{aligned}
$$

式 (2.6) の荷重項に関する部分以外は, いわゆる剛性 行列の要素を表わしている。以下, 荷重項の性質を調べ る。このために, 次の関数 $r(x), s(x), R(x), S(x)$ お よび定数 $\rho, \sigma$ を定義する：

$$
\begin{aligned}
& r(x)=\int_{0}^{x} \frac{l-z}{E I l} d z, R(x)=\int_{0}^{x} r(z) d z, \\
& s(x)=\int_{0}^{x} \frac{z}{E I l} d z, S(x)=\int_{0}^{x} s(z) d z, \\
& \rho \equiv r(l)=\alpha+\beta, \sigma \equiv s(l)=\beta+r . \cdots \cdots . .
\end{aligned}
$$

式 (2.5) および式 (2.7) より, 次の関係式が確かめら れる :

$$
\begin{aligned}
& \alpha=\frac{1}{l} R(l), \quad \gamma=\sigma-\frac{1}{l} S(l), \\
& \beta=\frac{1}{l} S(l)=\rho-\frac{1}{l} R(l) . \cdots .
\end{aligned}
$$

式 (2.5),(2.7)，(2.8）を用いて，式（2.6）の荷重項を 変形し, 整理すると,

$$
\begin{aligned}
& -\bar{\alpha} \mathfrak{U}-\bar{\beta} \mathfrak{B}=-\int_{0}^{l} \Phi_{2}(x) h(x) d x, \\
& -\bar{\rho} \mathfrak{A}-\bar{\gamma} \mathfrak{B}=\int_{0}^{l} \Phi_{4}(x) h(x) d x, \\
& \mathfrak{S}-\frac{\bar{\rho}-\bar{\alpha}}{l} \mathfrak{A}-\frac{\bar{\gamma}-\bar{\rho}}{l} \mathfrak{B}=\int_{0}^{l} \Phi_{1}(x) h(x) d x, \\
& \mathfrak{D}-\frac{\bar{\rho}-\bar{\alpha}}{l} \mathfrak{A}-\frac{\bar{r}-\bar{\beta}}{l} \mathfrak{B}=-\int_{0}^{l} \Phi_{3}(x) h(x) d x \text {. } \\
& \Phi_{1}(x) \equiv 1-\frac{1}{\Delta l}(\sigma R-\rho S), \\
& \Phi_{2}(x) \equiv x-\frac{1}{\Delta}(\gamma R-\beta S), \\
& \Phi_{3}(x) \equiv \frac{1}{\Delta l}(\sigma R-\rho S), \\
& \Phi_{4}(x) \equiv-\frac{1}{\Delta}(\beta R-\alpha S)
\end{aligned}
$$

の形で 表現されることがわかる。この $\Phi_{i}(x)$ といら関 数は一般には簡単な多項式等にはならないが, 数值的に は容易に求めることができる。

式 (2.9) によって, 式 (2.6) を書き直すと, 次の行 列の関係で表わされる :

$$
\boldsymbol{f}=-\boldsymbol{B} \boldsymbol{v}+\boldsymbol{c} .
$$

この式で, $\boldsymbol{f}$ と $\boldsymbol{c}$ は

$$
\boldsymbol{f}=\left[\begin{array}{c}
Q_{1} \\
-M_{1} \\
-Q_{2} \\
M_{2}
\end{array}\right], \quad \boldsymbol{c}=\left[\begin{array}{c}
c_{1} \\
c_{2} \\
c_{3} \\
c_{4}
\end{array}\right], \quad c_{i}=\left(\Phi_{i} h\right) \equiv \int_{0}^{l} \Phi_{i} h d x
$$

を表わし, $\boldsymbol{B}=\left(b_{i j}\right)$ は剛性行列を示す：

$$
\begin{aligned}
& b_{11}=\frac{\bar{\alpha}-2 \bar{\beta}+\bar{\gamma}}{l^{2}}, b_{12}=-\frac{\bar{\beta}-\bar{\alpha}}{l}, b_{13}=-b_{11}, \\
& b_{14}=\frac{\bar{\gamma}-\bar{\rho}}{l}, b_{22}=\bar{\alpha}, b_{23}=-b_{12}, b_{24}=-\bar{\beta}, \\
& b_{33}=b_{11}, b_{34}=-b_{14}, b_{44}=\bar{\gamma}, b_{i j}=b_{j i} .
\end{aligned}
$$

次に, $\Phi_{i}$ と $\Phi_{i}{ }^{\prime}$ の性質をみる。式 (2.7) の定義と式 (2.8) の関係から， $\Phi_{i}(x)$ について次の性質が明らかで ある :

$$
\begin{aligned}
& \Phi_{1}(0)=1, \Phi_{1}(l)=0, \Phi_{2}(0)=\Phi_{2}(l)=0, \\
& \Phi_{3}(0)=0, \Phi_{3}(l)=1, \Phi_{4}(0)=\Phi_{4}(l)=0 .
\end{aligned}
$$


また, $\Phi_{i}(x)$ の微係数 :

$$
\begin{aligned}
& \Phi_{1}{ }^{\prime}(x)=-\frac{1}{\Delta l}(\sigma r-\rho s), \\
& \Phi_{2}{ }^{\prime}(x)=1-\frac{1}{\Delta}(r r-\beta s), \\
& \Phi_{3}{ }^{\prime}(x)=\frac{1}{\Delta l}(\sigma r-\rho s)=-\Phi_{1}{ }^{\prime}(x), \\
& \Phi_{4}{ }^{\prime}(x)=-\frac{1}{\Delta}(\beta r-\alpha s)
\end{aligned}
$$

に対して, 次の性質も明らかである：

$$
\begin{aligned}
& \Phi_{1}{ }^{\prime}(0)=\Phi_{1}{ }^{\prime}(l)=0, \Phi_{2}{ }^{\prime}(0)=1, \Phi_{2}(l)=0, \\
& \Phi_{3}{ }^{\prime}(0)=\Phi_{3}{ }^{\prime}(l)=0, \Phi_{4}{ }^{\prime}(0)=0, \Phi_{4}{ }^{\prime}(l)=1
\end{aligned}
$$

式 (2.14) および式 (2.16) によって， $\Phi_{i}$ がいわゆる 変形関数の 1 組を与えることがわかる。一定断面のエレ メントにおいては， $\Phi_{i}$ は解析的に積分できて次の関倸 式をとる：

$$
\begin{aligned}
& \Phi_{1}(\xi)=1-3 \xi^{2}+2 \xi^{3}, \\
& \Phi_{2}(\xi)=l\left(\xi-2 \xi^{2}+\xi^{3}\right), \\
& \Phi_{3}(\xi)=3 \xi^{2}-2 \xi^{3}, \\
& \Phi_{4}(\xi)=l\left(-\xi^{2}+\xi^{3}\right), \quad \xi=\frac{x}{l} .
\end{aligned}
$$

さらに, $\Phi_{i}$ の定義によって, $\Phi_{i}$ が

$$
\frac{d^{2}}{d x^{2}} E I \frac{d^{2} \Phi_{i}}{d x^{2}}=0
$$

の解であることが知られる。他方, 求めるべき正確な変 位 $v(x)$ は式 (2.1), すなわち,

$$
\frac{d^{2}}{d x^{2}} E I \frac{d^{2} v}{d x^{2}}=h
$$

の解である。

いま一般に式(2.19) を解きたいものとして, 式(2.18) の解で式 (2.14) および式 (2.16) の境界条件が満たさ れる $\Phi_{i}$ を求めえたとする。このとき定数変化法にした がって式 (2.19) のvは次の形で表わされる：

$$
v=\Phi_{1} v_{1}+\Phi_{2} \theta_{1}+\Phi_{3} v_{2}+\Phi_{4} \theta_{2}+\sum_{i=1}^{4} u_{i}(x) \Phi_{i} .
$$

式 (2.20)の $u_{i}$ は次の関係式を満たす 4 つの関数とし て与えられている：

$$
\begin{aligned}
& \Sigma \Phi_{i} u_{i}{ }^{\prime}=0, \Sigma \Phi_{i}{ }^{\prime} u_{i}{ }^{\prime}=0, \Sigma \Phi_{i}{ }^{\prime \prime} u_{i}{ }^{\prime}=0, \\
& \Sigma \Phi_{i}{ }^{\prime \prime \prime} u_{i}{ }^{\prime}=\frac{h}{E I}, \\
& u_{1}(0)=u_{2}(0)=u_{3}(l)=u_{4}(l)=0 . \quad \cdots \cdots \cdots .
\end{aligned}
$$

式 (2.20) および式 (2.21) によって,

$$
\begin{aligned}
\int_{0}^{l} \Phi_{i} h d x= & \int_{0}^{l} \Phi_{i} \cdot \frac{d^{2}}{d x^{2}} E I \frac{d^{2} v}{d x^{2}} \\
= & -Q_{2} \delta_{i_{3}}+Q_{1} \delta_{i_{1}}+M_{2} \delta_{i 4}-M_{1} \delta_{i 2} \\
& +\int_{0}^{l} E I \frac{d^{2} v}{d x^{2}} \cdot \Phi_{i}^{\prime \prime} d x \quad(i=1 \sim 4)
\end{aligned}
$$

の右辺第 5 項を変形し整理すると, 式 (2.11) および式 (2.12) と全く同一の形で表わされる:

$$
\begin{gathered}
\boldsymbol{f}=-\boldsymbol{B} \boldsymbol{v}+\boldsymbol{c} \\
\text { こで, } b_{i j} \text { は } \\
b_{i j}=\left(\Phi_{i}{ }^{\prime \prime} E I \Phi_{j}{ }^{\prime \prime}\right)
\end{gathered}
$$

であるが, これは内容上, 式 (2.13) と一致すべきもの である。

以上の考察から次の結論がえられる。hが与えられた 関数ならば式 (2.1) あるいは式 (2.19) の解は式 (2.11) を解けば求められる。この際には方法上の誤差は含まれ ない。式 (2.11) の行列の要素は式 (2.18) の解から計 算される。式 (2.18) の解は一般に式 (2.10) で与えら れるが, 特に一定断面の場合には式 (2.17) で与えられ る。ここに述べたことは静力学でいわれていた変形法と 同一の内容のものである。

$h$ が与えられた関数のほかに $v$ または $v^{\prime}$ 等を含む 場合には別の問題が起こる。このような問題の基本とし て, 曲げ振動（ここでは固有振動）を考察する。

\section{3. 曲 げ振動}

振動計算においてモード解析の方法をとるとすれば, 各モードは式 $(2.1)$ で,

$$
h(x)=p^{2} m(x) v(x)
$$

とおいた解となる。ここで $p$ は固有円振動数を表わす。 式 (3.1) を式 (2.11) に代入した関係式ば末知の関数 $v(x)$ を含むのでこのままでは解けず，一般には何らか の近似法が必要となる。

いま（II）の立場から有限要素法を適用することを考 えてみる。式 (2.19) の解で式 (2.14) および式 (2.16) の境界条件を満たす関数を $F_{i}(x)$ とすれば, 式 (2.19) の正しい解（方法上の誤差を含まない解）は，

$$
v(x)=F_{1} v_{1}+F_{2} \theta_{1}+F_{3} v_{2}+F_{4} \theta_{2}
$$

の形で表わされる。ところが，（II）の定理によれば,

$$
\Phi \equiv \frac{p^{2} m l^{4}}{E I} .
$$

の值が小さいとき（どの程度小さければよいかは後でみ る）には, 式 (2.19) の解は $h=0$ とおいたときの解で 近似される。すなわち,

$$
v(x) \approx \Phi_{1} v_{1}+\Phi_{2} \theta_{1}+\Phi_{3} v_{2}+\Phi_{4} \theta_{2} .
$$

式 (3.4) を式 (3.1) の右辺におき, 式 (2.11) より次 の関係式がえられる：

$$
\boldsymbol{f}=-\boldsymbol{B} \boldsymbol{u}+p^{2} \boldsymbol{C} \boldsymbol{v} .
$$

式 (3.5) の $\boldsymbol{C}$ 海量行列を表わす:

$$
\boldsymbol{C}=\left(m_{i j}\right), m_{i j}=\left(\Phi_{i} m \Phi_{j}\right) \text {. }
$$

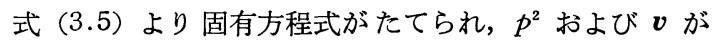
求められる。残る問題は式 (3.2) と式 (3.4) との近似 
の度合いである。微分方程式の解は一般には係数を定め るパラメーターに連続的に依存するので，一定断面のエ レメントを考えれば傾向を知ることができる。

$E I$ および $m$ が定数であるとき, 式 (2.19) の解 $v(x)$ :

$$
E I \frac{d^{4} v}{d x^{4}}=p^{2} m v
$$

は解析的に解けて， $F_{i}(x)$ は次の形で表わされる：

$$
\begin{aligned}
& F_{1}(\xi)= \frac{1}{2 f_{10}}\{(\cot \phi+\operatorname{coth} \phi)(\sinh \phi \xi-\sinh \phi \xi) \\
&\left.+\left(f_{10}+1\right) \cos \phi \xi+\left(f_{10}-1\right) \cosh \phi \xi\right\}, \\
& F_{2}(\xi)= \frac{l}{2 f_{10} \cdot \phi}\left\{\left(f_{10}-1\right) \sin \phi \xi+\left(f_{10}+1\right) \sinh \phi \xi\right. \\
&+(\operatorname{coth} \phi-\cot \phi)(\cos \phi \xi-\cosh \phi \xi)\}, \\
& F_{3}(\xi)= F_{1}(1-\xi), F_{4}(\xi)=-F_{2}(1-\xi), \\
& \phi=\sqrt[4]{\frac{m}{E I}} \cdot \sqrt{p} \cdot l, \xi=\frac{x}{l}, \\
& f_{10}=\operatorname{cosech} \phi \operatorname{cosec} \phi-\operatorname{coth} \phi \cot \phi . \quad \cdots \cdots(3.7)
\end{aligned}
$$

“悠密な”変形関数 (3.7) は $\phi$ をパラメーターとして おり, 若干個の $\phi$ について $\xi$ の関数として表示すると 図一1 のとおりである。これに対して“近似的な”变形 関数 (2.17) (一定断面であるので) は，このグラフに おいて $\phi=0$ ( $\phi=0.1$ の曲線にほとんど一致する) の曲 線にあたる。このグラフから $F_{i}$ と $\Phi_{i}$ との差は, $\phi=$ 0 付近ではほとんど 0 に等しいが， $\phi$ が増大するにつれ
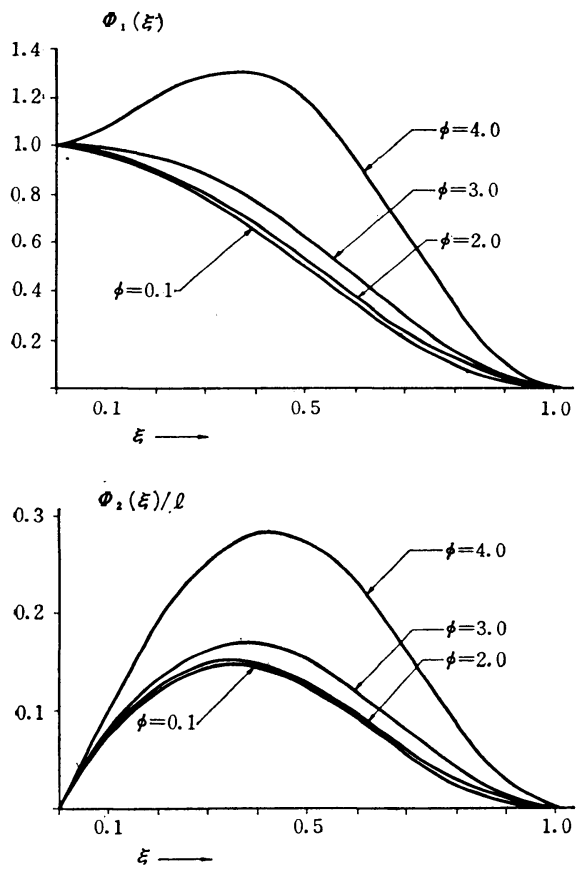

図一1 等断面の場合の変形関数（解析的な解）

$$
\phi=\sqrt[4]{\frac{m}{E I}} \cdot l \cdot \sqrt{p}
$$

一式(3.7) の $F_{1}(\xi), F_{2}(\xi) / l$
て増大する。

以上は 1 エレメントについての誤差であり，実際には エレメントがいくつか結合することによって生じる誤差 も方法上の誤差にはいる。この誤差はエレメントの結合 の状況やモードの現われ方にも関係して, 前もって推定 することは困難であろらが，いくつかの試算によれば， 個々のエレメントについて

$$
\phi=\sqrt[4]{\frac{m}{E I}} \cdot \sqrt{p} \cdot l \approx 1.0
$$

が近似性の大よその基準とされる。

したがって，すでに述べたように，一般に変断面のエ レメントについても,

$$
\Phi=\frac{m}{E I} \cdot p^{2} l^{4} \approx 1.0
$$

をおおよその基準とすることができる。すなわち，lを 定めておけば, 式 (3.8) を満足する $p$ までがほぼ良好 な固有值とみなされ，また，ある大きさの $p$ まで必要 なときには式 (3.8) を满足するようにlを小さくして おかなければならない。

次に（I）の立場から有限要素法を適用することを考 える。この場合, 一定断面であると変断面であるとにか かわらず式 (2.17) の変形関数 $\Phi_{i}$ がとられるのが普通 である ${ }^{2)}$ 。求める関数 $v(x)$ を $\Phi_{i}$ で近似させて, エネ ルギー原理を用いつりあいの式をたてる。この式の諸要 素を個々のエレメントについてみると，式 (3.5) の右 辺:

$$
-\boldsymbol{B} \boldsymbol{v}+p^{2} \boldsymbol{C v}
$$

の形をしている。つりあいの式は式 (3.9) をよせ集め た和が 0 になるといら形式になっている。

式（3.9）を応力 $\boldsymbol{f}$ の式とみなせば，形式上は（II） の立場の関係式 (3.5) と全く同一になる。ただし，こ のなかに入っている $\Phi_{i}$ が異なっている。（II）の立場 では, 変形関数は式 (2.14) および式 (2.16) の境界条 件をみたせばある程度自由であるが，变形関数の選択や エレメントの大きさの判断と結果の近似性とを結びつけ る簡略な基準がないように思われる。

また，（I）の立場では応力は変形が求められたのち に, これを微分して求めることが多いが, この結果は式 (3.9) より出した值（エレメントの端点の応力）といく らかくい違っている。式 (3.9) より求めた值は (II) の 方法の結果と近い值で連続的となり，(II）の方法の結 果を smoothing した形になっている（次節の数值例参 照)。数值例に入るまえに，応用上必要である振動系の 縮小について検討する。 


\section{4. 振動系の縮小}

いくつかのエレメントが結合した系における独立変数 を $\boldsymbol{v}$, 剛性行列を $\boldsymbol{B}$, 質量行列を $\boldsymbol{C}$ と表わし, $\lambda=p^{2}$ を 円振動数とする。系を二つの部分に分け，対応する変数 を $\boldsymbol{v}_{1}, \boldsymbol{v}_{2}$ とし $, \boldsymbol{B}, \boldsymbol{C}$ も相応に分割する。すなわち，

$$
\boldsymbol{v}=\left[\begin{array}{l}
\boldsymbol{v}_{1} \\
\boldsymbol{v}_{2}
\end{array}\right], \quad B=\left[\begin{array}{ll}
\boldsymbol{B}_{11} & \boldsymbol{B}_{12} \\
\boldsymbol{B}_{21} & \boldsymbol{B}_{22}
\end{array}\right], \boldsymbol{C}=\left[\begin{array}{ll}
C_{11} & C_{12} \\
C_{21} & C_{22}
\end{array}\right]
$$

なる関係がある。 $\boldsymbol{B}$ と $\boldsymbol{C}$ は対称行列である。全体の系 の固有方程式は

$$
B \boldsymbol{v}=\lambda \boldsymbol{C v}
$$

で表わされる。

いま,この全体系から $v_{1}$ の部分を省略して近似的な 縮小系をつくる操作と, その近似の度合を考える。

Ramden と Stoker はエネルギ一原理から出発して， 縮小系をつくるルーチンを与えている4)が，ここでは直 接に式 (4.2) より出発して縮小が可能である条件をみ る。まず, 式 (4.2) を二つの部分に分けて表わす：

$$
\begin{aligned}
& B_{11} v_{1}+B_{12} v_{2}=\lambda\left(C_{11} v_{1}+C_{12} v_{2}\right), \\
& B_{21} v_{1}+B_{22} v_{2}=\lambda\left(C_{21} v_{1}+C_{22} v_{2}\right) .
\end{aligned}
$$

式 (4.3) の第 1 式より $\boldsymbol{v}_{1}$ を求め:

$$
v_{1}=\left(1-\lambda B_{11}^{-1} C_{11}\right)^{-1}\left(\lambda B_{11}^{-1} C_{12}-B_{11}^{-1} B_{12}\right) v_{2}
$$

この逆行列の部分が展開できるとしてみる :

$$
\begin{aligned}
\boldsymbol{v}_{1}= & \left(-B_{11}^{-1} B_{12}+\lambda B_{11}^{-1} C_{12}\right. \\
& \left.-\lambda B_{11}^{-1} C_{11} B_{11}^{-1} B_{12} \cdots\right) v_{2} .
\end{aligned}
$$

式 (4.3) の第 1 式において $v_{1}$ の部分だけをとってそ の固有値を と省をと，

$$
B_{11} v_{1}=\mu C_{11} v_{1} \text { または } B_{11}^{-1} C_{11} v_{1}=\frac{1}{\mu} u_{1}
$$

であるが， $\mu^{-1}$ の最大值 $\max \mu^{-1}$ に対して，

$$
\lambda \max \mu^{-1}=\frac{\lambda}{\min \mu} \ll 1.0
$$

ならば, 式 (4.4) の展開が可能であり,かつ, 最初の 3 項のみをとり, 残りを省略しても, よい近似がえられ る。このとき，

$$
v_{1}=-B_{11}^{-1} B_{12} v_{2}+\lambda B_{11}^{-1}\left(C_{12}-C_{11} B_{11}^{-1} B_{12}\right) v_{2}
$$

を式 (4.3) の第 2 式に代入して，縮小系の固有方程式 がえられる：

$$
\begin{aligned}
& B_{22} * v_{2}=\lambda C_{22}^{*} v_{2}, \\
& B_{22}^{*}= B_{22}-B_{21} B_{11}^{-1} B_{12}, \\
& C_{22} *= C_{22}+B_{21} B_{11}^{-1} C_{11} B_{11}^{-1} B_{12} \\
&-B_{21} B_{11}^{-1} C_{12}-C_{21} B_{11}^{-1} B_{12}
\end{aligned}
$$

式 (4.8) の結果は前掲論文 $\left.{ }^{4}\right)$ の結果と 同じ形式である が, 式 (4.7) の $v_{1}$ の関係式では右辺第 2 項がある点 だけ異なっている。後の数值例でみるように, この項は

あまり大きい効果を与えない。

\begin{tabular}{|c|c|c|c|}
\hline \multirow{2}{*}{ 次数 } & $A$ & \multicolumn{2}{|c|}{$B$} \\
\hline & $\lambda(T$ sec $)$ & $\lambda(T \mathbf{s e c})$ & $\phi$ \\
\hline 1 & $\begin{array}{l}18.73 \\
(1.452)\end{array}$ & $\begin{array}{l}18.75 \\
(1.451)\end{array}$ & 1. \\
\hline 2 & $\begin{array}{l}603.5 \\
(0.256)\end{array}$ & $\begin{array}{l}608.1 \\
(0.255)\end{array}$ & 41 \\
\hline 3 & $\begin{array}{l}6266 \\
(0.079)\end{array}$ & $\begin{array}{l}6539 \\
(0.078)\end{array}$ & 440 \\
\hline
\end{tabular}

\section{数 值 例}

テーパーのついたカンチレバーの横振動を考える。 $x$ 軸を長手の方向にとって, 断面二次モーメントと単位長 あたり質量は,

$$
\begin{aligned}
& I(x)=I(0)\left(\frac{l_{0}+x}{l_{0}}\right)^{2} \\
& m(x)=m(0) \frac{l_{0}+x}{l_{0}}, 0 \leq x \leq l
\end{aligned}
$$

の形で表わされ， $x=0$ が自由端， $x=l$ が固定端に対 忘するものとする。これらの量に次の数值を与える :

$E I(0)=3.0 \times 10^{5} \mathrm{t} \cdot \mathrm{m}^{2}, m(0)=2.0 \mathrm{t} \cdot \mathrm{sec}^{2} / \mathrm{m}^{2}$, $l_{0}=50.0 \mathrm{~m}, l=20.0 \mathrm{~m}$.

最初に各節点に $v$ および $\theta$ の 2 変数をとる場合をみ

表一1 周期 (横振動) … 2 エレメント系 $\phi=\frac{m \lambda(\Delta x)^{4}}{E I}$

であり， $B$ は (II) の立場から (2.10) の変形関数を適 用する方法である。Bでは無名数 :

$$
\phi=\frac{\lambda m}{E I}(\Delta x)^{4}
$$

の大きさによって, 解の近似の度合いが判断されるの で，この值を並記してある。ただし， で最も大きい值 $(x=0$ の位置）を示している。

\begin{tabular}{|c|c|c|c|}
\hline & \multicolumn{3}{|c|}{ 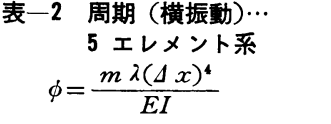 } \\
\hline \multirow{2}{*}{ 次 数 } & A & \multicolumn{2}{|c|}{ B } \\
\hline & $\lambda(T$ sec $)$ & $\lambda(T \sec )$ & $\phi$ \\
\hline 1 & $\begin{array}{r}18.66 \\
(1.452)\end{array}$ & $\begin{array}{r}18.72 \\
(1.452)\end{array}$ & 0.03 \\
\hline 2 & $\begin{array}{r}597.6 \\
(0.257)\end{array}$ & $\begin{array}{r}598.1 \\
(0.257)\end{array}$ & 1.0 \\
\hline 3 & $\begin{array}{r}4434 \\
(0.094)\end{array}$ & $\begin{array}{r}4438 \\
(0.094)\end{array}$ & 7.6 \\
\hline 4 & $\begin{array}{r}17000 \\
(0.048)\end{array}$ & $\begin{array}{r}17030 \\
(0.048)\end{array}$ & 29 \\
\hline 5 & $\begin{array}{r}46610 \\
(0.029)\end{array}$ & $\begin{array}{r}46590 \\
(0.029)\end{array}$ & 80 \\
\hline
\end{tabular}

表一1によると（I）の方法と（II）の方法との固有 值の差はたかだか数％である。(II) の方法からすれば 3 次の固有值は精度がおとり $(\phi=440)$, 分割数をませ ばかなり変動するものであることが推定できる。

$$
\text { 表一2 は } 5 \text { エレメ }
$$

ントで計算した結果 である。精度の点か らみると， 3 次まで が信頼度が高くそれ 以上はまだかなり動 摇しているものと推 定できる。

次に応力の応答量 をみる。ここに応答 とは, 底端の単位加 速度に対していう。 

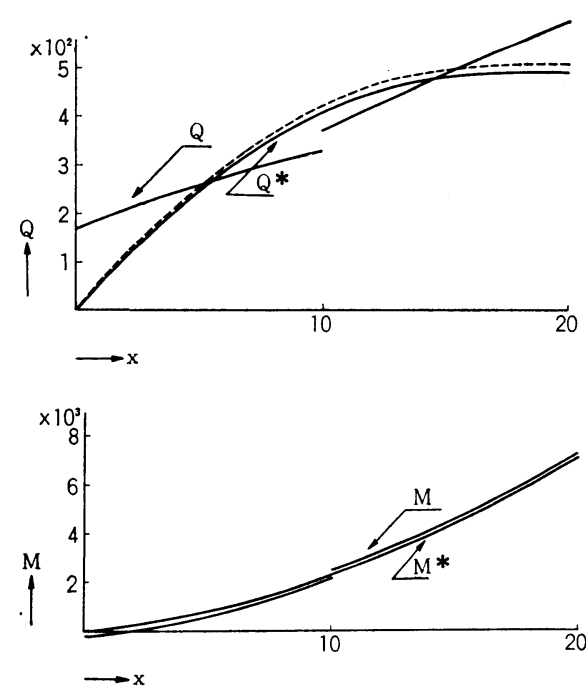

図一2 曲げモーメントおよびせん断力の応答

(1) $M, Q \cdots \mathrm{A}$ のケース, $M^{*}, Q^{*} \cdots \mathrm{B}$ のケース

（2）実線は 2 エレメント，点線は 5 エレメント

图一2 に曲げモーメント $M$ およびせん断力 $Q$ のダイ ヤグラムが示されている。実線は 2 エレメント系の 1 次 振動の応答, 点線は 5 エレメント系の 1 次振動の応答で ある。ただし，曲げモーメント $M$ については実線と点 線がほとんど一致しているので, 点線が表示されていな い。

（*) をつけたカーブは（II）の方法の值で連続的であ るが，（I）の方法では節点でいくらか不連続を生じる。 しかし, 式 (3.9) のところで述べた関係式をとれば, (II) の方法によるカーブにほとんど一致することが知 られる。(*) をつけたカーブは（*) をつけないカーブ を smoothing した結果とみなすこともできる。節点に おける不連続量は $\lambda$ の小さい領 域（低次の範囲）では 小さい。また, 曲げモーメントについては特に小さい。 これは回転慣性の作用の小さいことを示す。

次に振動系の縮小の問題に移る。うえに述べたことか ら， $\theta$ 成分を省略することを考える。 5 エレメント系に おいて, 最初に $\theta$ を 5 つ, ついで $v$ を 5 つ並べて, そ れぞれを $v_{1}$ および $v_{2}$ とし，対応して剛性行列と質量 行列も並べかえておく。

\begin{tabular}{|c|c|c|}
\hline \multicolumn{3}{|c|}{$\begin{array}{c}\text { 表一3 縮小系の固有值 } \\
\text { …..5: エレメント系 } \\
\bar{\lambda} \text { は縮小系の固有値 }\end{array}$} \\
\hline \multirow{2}{*}{ 次数 } & \multicolumn{2}{|c|}{ B } \\
\hline & $\lambda$ & $\bar{\lambda}$ \\
\hline 1 & 18.72 & 18.72 \\
\hline 2 & 598.1 & 598.9 \\
\hline 3 & 4438 & 4486 \\
\hline 4 & 17030 & 17700 \\
\hline 5 & 46590 & 47730 \\
\hline
\end{tabular}

式 (4.5) を解いてみると， $\min \mu=84710$

であることがわかる。式 (4.8) にしたがって，縮小された系の 算出を行なうと，表一3 の結果 がえられる。これは 5 元で最大 のגについて,

$$
\frac{\max \lambda}{\min \mu}=0.56
$$

となっており，縮小可能の条件が満たされている。もと の系と縮小系の固有值については，1.2 次では $1 \%$ 以 内, 3 次は $1 \%$ 程度, 4.5 次は数\%程度の開きである。 両者の開きは 表一2 の фに対応していることがわかる。

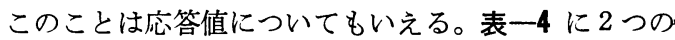
系の応力の対照が 示されているが， 1.2 次では 1 2\% の開き， 3 次ではやや開きが増大している。

\section{表一4 応答值（横振動）‥5 エレメント系}

$M, Q$ むとの系の応力

$\bar{M}, \bar{Q}$ 縮小系の応力

$\bar{M}^{\prime}, \bar{Q}^{\prime}$ 縮小系で式 (4.7) の右辺第 2 項を省略する

\begin{tabular}{|c|c|c|c|c|c|c|}
\hline \multirow{2}{*}{$\frac{x}{l}$} & \multicolumn{3}{|r|}{ 次 } & - & \multicolumn{2}{|l|}{ 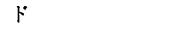 } \\
\hline & $M$ & $\bar{M}$ & $\bar{M}^{\prime}$ & $Q$ & $\bar{Q}$ & $\overline{\mathbf{Q}}^{\prime}$ \\
\hline 0.2 & -449.4 & -450.7 & -436.9 & 215.6 & 216.1 & 194.8 \\
\hline 0.4 & -1645 & -1650 & -1666 & 372.0 & 373.1 & 385.5 \\
\hline 0.6 & -3342 & -3351 & -3358 & 466.5 & 467.9 & 470.2 \\
\hline 0.8 & -5304 & -5318 & -5325 & 506.5 & 507.9 & 511.9 \\
\hline 1.0 & -7349 & -7368 & -7370 & 512.9 & 514.3 & 515.3 \\
\hline \multirow{2}{*}{$\frac{x}{l}$} & \multicolumn{6}{|c|}{2} \\
\hline & $M$ & $\bar{M}$ & $\bar{M}^{\prime}$ & $Q$ & $\bar{Q}$. & $\overline{\mathbf{Q}}^{\prime}$ \\
\hline 0.2 & 6378 & 6517 & 6660 & -2485 & -2542 & -2333 \\
\hline 0.4 & 14570 & 14890 & 15400 & -1061 & -1086 & -1453 \\
\hline 0.6 & 12180 & 12450 & 12380 & 2346 & 2397 & 2416 \\
\hline 0.8 & -3015 & -3076 & -3397 & 4925 & 5035 & 5171 \\
\hline 1.0 & -24370 & -24910 & -25060 & 5488 & 5611 & 5721 \\
\hline \multirow{2}{*}{$\frac{x}{l}$} & \multicolumn{6}{|c|}{ 次 } \\
\hline & $M$ & $\bar{M}$ & $\bar{M}^{\prime}$ & $Q$ & $\bar{Q}$ & $\bar{Q}^{\prime}$ \\
\hline 0.2 & -19210 & -20780 & -22360 & 4846 & 5297 & 4904 \\
\hline 0.4 & -15210 & -16350 & -16060 & -7042 & -7601 & -6793 \\
\hline 0.6 & 18140 & 19400 & 22650 & -5941 & -6413 & -8154 \\
\hline 0.8 & 12600 & 13570 & 12520 & 8880 & 9560 & 9554 \\
\hline 1.0 & -38190 & -41080 & -42230 & 14180 & 15290 & 16140 \\
\hline
\end{tabular}

以上の考察によって, 近似の度合は $\phi$ の大きさによっ て判断できることがわかる。そのほかのいくつかの試算 （6. の例も参照）によると, 最も信頼の高いのは $\phi \approx$ 1.0 程度までである。

表一4 には式 (4.7) で右辺第 2 項を省略した場合の 応答值も示されている。1 次ではこの効果は数\%以内で あるが， 2 次・ 3 次になるとやや増加して，ところどこ ろ 10\%を越えている。このような点では，両側の応力 がくい違って不連続がおこっている。両側の值を平均し てみれば, 数\%程度の誤差である。それで，この点を許 容すれば式（4.7）で第 2 項は省略してよいことになる。

\section{5. 繸 振 動}

ここでは縦振動そのものを調べることではなく，次節 に進む予備として 2 階微分方程式の型の変形関数をみて おく必要があるので, その具体的な例として, 縦振動の 型を考察する。 
軸方向の変位を $u=u(x)$ とし, 断面積 $A$ が $x$ の関 数であるとすれば, 綐振動のモードを定める関係式は

$$
\frac{d N}{d x}=-p^{2} m u, N=E A \frac{d u}{d x}
$$

となる。ここで $N$ は軸方向の応力を表わす。

この問題の変形関数は

$$
\frac{d}{d x} E A \frac{d u}{d x}=0 \text {. }
$$

の解から決定される。エレメントの両端における変位を $u_{1}, u_{2}$ とし, 応力を $N_{1}, N_{2}$ と表わす。変形関数 $\Psi_{1}(x)$,

$\Psi_{2}(x)$ に対する境界条件は,

$$
\Psi_{1}(0)=1, \Psi_{2}(0)=0, \Psi_{1}(l)=0, \Psi_{2}(l)=1
$$

である。

関数 $t(x)$ と定数 $\tau$ :

$$
t(x)=\int_{0}^{x} \frac{d x}{E A}, \tau=t(l)
$$

を定義すると， $\Psi_{i}$ は次の形で表わされる：

$$
\Psi_{1}(x)=1-\frac{t}{\tau}, \Psi_{2}(x)=\frac{t}{\tau}
$$

特に一定断面ならば,

$$
\Psi_{1}(\xi)=1-\xi, \Psi_{2}(\xi)=\xi, \xi=\frac{x}{l}
$$

となる。

うえの変形関数に対する剛性行列の要素 $b_{i j}$ は,

$$
b_{11}=\frac{1}{\tau}, b_{12}=-b_{11}, b_{22}=b_{11}
$$

である。このとき, 式 (5.1) の解は次の関係式の解で 表わされる：

$$
\begin{aligned}
& N_{1}=\frac{1}{\tau}\left(u_{2}-u_{1}\right)+p^{2} \int_{0}^{l} m u \Psi_{1} d x, \\
& -N_{2}=\frac{1}{\tau}\left(u_{1}-u_{2}\right)+p^{2} \int_{0}^{l} m u \Psi_{2} d x .
\end{aligned}
$$

有限要素法の手法に従って, 右辺の $u$ について,

$$
u \approx \Psi_{1}(x) u_{1}+\Psi_{2}(x) u_{2}
$$

と近似できれば式 (5.5) は解くことができる。

式 (5.6) の近似が可能である条件をみるために，一 定断面の場合の “厳密な” 変形関数 $F_{1}(\xi), F_{2}(\xi)$ :

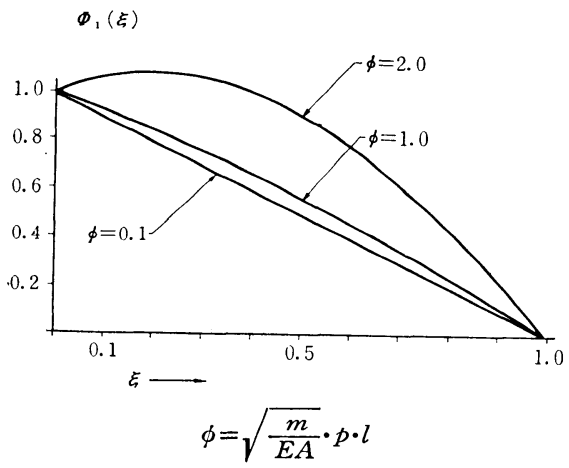

一式 (5.7) の $F_{1}(\xi)$

図一3 等断面の場合の变形関数 (解析的な解)

$$
\begin{aligned}
& F_{1}(\xi)=\frac{\sin \phi(1-\xi)}{\sin \phi}, F_{2}(\xi)=F_{1}(1-\xi), \\
& \phi=\sqrt{\frac{m}{E A}} \cdot p \cdot l \quad \ldots \ldots \ldots \ldots \ldots \ldots \ldots \ldots \ldots \ldots \ldots \ldots \ldots \ldots \ldots \ldots \ldots
\end{aligned}
$$

のグラフをみてみよう(図一3)。式 (5.4) はこのグラ フで $\phi \approx 0$ の極限にあたるが, $\phi=0.1$ 程度ではほとん ぞ両者の差異はなく, $\phi=1.0$ ではいくらか差異をみせ る。

したがって，式 (5.6) の成り立つ条件は

$$
\Phi=\frac{m}{E A} p^{2} \cdot l^{2} \approx 1.0
$$

の範囲であるが， 4 階の型の場合と比べて，条件をきつ く（あを小さくとる）とった方がよい近似を与えるよう である。

\section{Timoshenko beam の固有振動}

Timoshenko beam は次の形の固有振動方程式を有す る :

$$
\begin{aligned}
& \frac{d}{d x} \kappa G A\left(\frac{d v}{d x}-\theta\right)=-m p^{2} v, \\
& \frac{d}{d x} E I \frac{d \theta}{d x}+\kappa G A\left(\frac{d v}{d x}-\theta\right)=-m r^{2} p^{2} \theta .
\end{aligned}
$$

この式で $\kappa$ は断面形状に関する定数であり， 面の回転半径を示す。 $r^{2}$ は $I / A$ に等しく, また, 材質 の密度を $\rho$ とすれば, $m=\rho A$ となる。

一般に断面が $x$ とともに変化する場合に, 式(6.1) を 解くことを考える。式 (6.1) を次の形式:

$$
\begin{aligned}
& \frac{d}{d x} \kappa G A \frac{d v}{d x}=\frac{d}{d x} \kappa G A \theta-m p^{2} v, \\
& \frac{d}{d x} E I \frac{d \theta}{d x}=-\kappa G A\left(\frac{d v}{d x}-\theta\right)-m r^{2} p^{2} \theta .
\end{aligned}
$$

に表わしてみると, 式 (6.2) の左辺は 2 階の微分方程 式になるので, $v$ および $\theta$ のそれぞれについて式 (5.3) または式 (5.4) の型の変形関数の適用が 考虑される。 しかし, この型の変形関数の適用は良い近似を与えない ことが多い。P. Tong はこの問題の困難な 点を説明し ている3)。

（II）の立場から考えると, 式 (6.2) に2 階の型の変 形関数が適用できるのは, $\Delta x$ をエレメントの長さとし $\tau$,

$$
\begin{aligned}
& \frac{\kappa G A}{\kappa G A}, \frac{m p^{2}(\Delta x)^{2}}{\kappa G A}, \frac{\kappa G A(\Delta x)^{2}}{E I}, \\
& \frac{m r^{2} p^{2}(\Delta x)^{2}}{E I}
\end{aligned}
$$

のそれぞれの值が 1.0 程度以下でなければならない。 たとえば式 (6.3) の第 3 の量をとると, 


$$
\frac{\kappa G A(\Delta x)^{2}}{E I}=\frac{\kappa G}{E}\left(\frac{\Delta x}{r}\right)^{2}
$$

であるので，rの小さいビームは分割を非常に細かくし なければならない。また，第 1 の量はつねに 1.0 より 小さくできない。このような数量的関係があるので, 式 (6.1) にv および $\theta$ のそれぞれについての 2 階の型の 変形関数を適用することは, 能率的でない。

それゆえ，

$$
\begin{aligned}
& \frac{d}{d x} \kappa G A\left(\frac{d v}{d x}-\theta\right)=0, \\
& \frac{d}{d x} E I \frac{d \theta}{d x}+\kappa G A\left(\frac{d v}{d x}-\theta\right)=0 .
\end{aligned}
$$

の形の方程式より, 変形関数を導いてみる。この変形関 数の適用は,

$$
\frac{m p^{2}(\Delta x)^{2}}{\kappa G A} \approx 1.0, \frac{m r^{2} p^{2}(\Delta x)^{2}}{E I} \approx 1.0
$$

の範囲でよい近似を与えるであろう。 ば, 式 (6.5) のうちで前者が大きいので, この変形関 数の適用の範囲は $\phi:$

$$
\phi=\frac{m p^{2}(\Delta x)^{2}}{\kappa G A} \approx 1.0
$$

で与えられる。

曲げモーメント $M$ およびせん断力 $Q$ の関係式：

$$
M=-E I \frac{d \theta}{d x}, Q=\kappa G A\left(\frac{d v}{d x}-\theta\right) .
$$

を用いて式 (6.4) を積分する演算は 2. と同様である ので省略して結果のみ説明する。記号も 2. 3. と同様 にとり， $x=0$ を 1 端とし， $x=l$ を 2 端としたエレメン トを考えている。

関数 $s_{1 \theta}(x), s_{2 \theta}(x), t_{\theta}(x), t_{1 \theta}(x), t_{2 \theta}(x), t_{v}(x)$ と 定数 $\sigma_{1 \theta}, \sigma_{2 \theta}, \tau_{\theta}, \tau_{1 \theta}, \tau_{2 \theta}, \tau_{v}$ を定義する：

$$
\begin{aligned}
& s_{1 \theta}=\int_{0}^{x} \frac{z}{E I} d z, s_{2 \theta}=\int_{0}^{x} s_{1 \theta}(z) d z, \\
& \sigma_{1 \theta}=s_{1 \theta}(l), \sigma_{2 \theta}=s_{2 \theta}(l), \\
& t_{\theta}=\int_{0}^{x} \frac{d z}{E I}, t_{1 \theta}=\int_{0}^{x} t_{\theta}(z) d z, \\
& \tau_{\theta}=t_{\theta}(l), \tau_{1 \theta}=t_{1 \theta}(l), \\
& t_{2 \theta}=\int_{0}^{x} t_{1 \theta}(z) d z, \tau_{2 \theta}=t_{2 \theta}(l), \\
& t_{v}=\int_{0}^{x} \frac{d z}{\kappa G A}, \tau_{v}=t_{v}(l) .
\end{aligned}
$$

この定数のあいだには次の関係が成りたっている：

$$
\sigma_{1 \theta}=l \tau_{\theta}-\tau_{1 \theta}, \sigma_{2 \theta}=l \tau_{1 \theta}-2 \tau_{2 \theta} .
$$

次に関数 $P_{0}(x), P_{1}(x), P_{2}(x), P_{3}(x)$ を定義する：

$$
\begin{aligned}
& P_{0}(x)=\frac{1}{\Delta}\left(-\tau_{\theta}+t_{\theta}\right), P_{1}(x)=\frac{1}{\Delta}\left(-\tau_{1 \theta}+t_{1 \theta}\right), \\
& P_{2}(x)=\frac{1}{\Delta}\left\{-\tau_{1 \theta}+t_{1 \theta}+(l-x) t_{\theta}\right\}, \\
& P_{3}(x)=\frac{1}{\Delta}\left\{-2 \tau_{2 \theta}+2 t_{2 \theta}+(l-x) t_{1 \theta}-\tau_{v}+t_{v}\right\},
\end{aligned}
$$

$$
\Delta \equiv \sigma_{1 \theta} \tau_{1 \theta}-\tau_{\theta}\left(\sigma_{2 \theta}-\tau_{v}\right) .
$$

以上の定義によって, $v$ および $\theta$ に対する変形関数 として $\Psi_{i}(x)$ および $\Phi_{i}(x)(i=1 \sim 4)$ が導かれる：

$$
\begin{aligned}
& \Psi_{1}=\tau_{1 \theta} P_{1}-\tau_{\theta} P_{3}, \\
& \Psi_{2}=\left(\sigma_{2 \theta}-\tau_{v}\right) P_{1}-\sigma_{1 \theta} P_{3}-(l-x), \\
& \Psi_{3}=1-\Psi_{1}, \\
& \Psi_{4}=\left(2 \tau_{2 \theta}+\tau_{v}\right) P_{1}-\tau_{1 \theta} P_{3}, \\
& \Phi_{1}=\tau_{1 \theta} P_{0}-\tau_{\theta} P_{2}, \\
& \Phi_{2}=\left(\sigma_{2 \theta}-\tau_{v}\right) P_{0}-\sigma_{1 \theta} P_{2}, \\
& \Phi_{3}=-\Phi_{1}, \\
& \Phi_{4}=\left(2 \tau_{2 \theta}+\tau_{v}\right) P_{0}-\tau_{1 \theta} P_{2}+1 \ldots \ldots . . . .
\end{aligned}
$$

式 (6.11) が変形関数として必要な境界条件を満たすこ とは確かめることができる。

この変形関数を用いて, 一般に,

$$
\begin{aligned}
& \frac{d}{d x} \kappa G A\left(\frac{d v}{d x}-\theta\right)=-q_{v}, \\
& \frac{d}{d x} E I \frac{d \theta}{d x}+\kappa G A\left(\frac{d v}{d x}-\theta\right)=-q_{\theta}
\end{aligned}
$$

の解は, 次の応力-変形関係の解に帰着される :

$$
\begin{aligned}
& \boldsymbol{f}=-\boldsymbol{B} \boldsymbol{v}+\boldsymbol{c}, \\
& \boldsymbol{B}=\left(b_{i j}\right), b_{i j}=b_{j i}, \boldsymbol{c}=\left(c_{i}\right) \\
& b_{11}=\frac{\tau_{\theta}}{\Delta}, b_{12}=\frac{\sigma_{1 \theta}}{\Delta}, b_{13}=-b_{11}, b_{14}=\frac{\tau_{1 \theta}}{\Delta}, \\
& b_{22}=\frac{1}{\Delta}\left(-\sigma_{2 \theta}+\tau_{v}+\sigma_{1 \theta} l\right), b_{23}=-b_{12}, \\
& b_{24}=\frac{1}{\Delta}\left(\sigma_{2 \theta}-\tau_{v},\right) b_{33}=b_{11}, b_{34}=-b_{14}, \\
& b_{44}=\frac{1}{\Delta}\left(-\sigma_{2 \theta}+\tau_{v}+\tau_{1 \theta} l\right), \\
& c_{i}=\int_{0}^{l} \Psi_{i} q_{v} d x+\int_{0}^{l} \Phi_{i} q_{\theta} d x, i, j=1 \sim 4 \ldots(6.1
\end{aligned}
$$

式 (6.12) の解 $\boldsymbol{v}$ を用いて, $v$ と $\theta$ は次の式で近似さ れる :

$$
\begin{aligned}
& v=\Psi_{1} v_{1}+\Psi_{2} \theta_{1}+\Psi_{3} v_{2}+\Psi_{4} \theta_{2}, \\
& \theta=\Phi_{1} v_{1}+\Phi_{2} \theta_{1}+\Phi_{3} v_{2}+\Phi_{4} \theta_{2} .
\end{aligned}
$$

もし， $q_{v}$ と $q_{\theta}$ が与えられた関数ならば式 (6.12)の 解は方法上の誤差を含まない正確な解である。これは静 力学でいわれていた変形法の公式に一致すべきものであ る。

一定断面の場合には剛性行列および変形関数は次のと おりになる :

$$
\begin{aligned}
& \delta \equiv \frac{12 E I}{\kappa G A l^{2}} \text { とおいて, } \\
& b_{11}=\frac{12 E I}{l^{3}} \frac{1}{1+\delta}, b_{12}=\frac{6 E I}{l^{2}} \frac{1}{1+\delta}, b_{14}=b_{12}, \\
& b_{22}=\frac{4 E I}{l} \frac{1+\frac{\delta}{4}}{1+\delta}, b_{24}=\frac{2 E I}{l} \frac{1-\frac{\delta}{2}}{1+\delta}, b_{44}=b_{22}, \\
& \Psi_{1}(\xi)=\frac{1-\xi}{1+\delta}\left(1+\xi-2 \xi^{2}+\delta\right),
\end{aligned}
$$




$$
\begin{aligned}
& \Psi_{2}(\xi)=\frac{l \xi(1-\xi)}{1+\delta}\left(1-\xi+\frac{\delta}{2}\right), \\
& \Psi_{3}(\xi)=\Psi_{1}(1-\xi), \Psi_{4}(\xi)=-\Psi_{2}(1-\xi), \\
& \Phi_{1}(\xi)=-\frac{6 \xi(1-\xi)}{(1+\delta) l}, \Phi_{2}(\xi)=\frac{1-\xi}{1+\delta}(1-3 \xi+\delta), \\
& \Phi_{3}(\xi)=-\Phi_{1}(1-\xi), \Phi_{4}(\xi)=\Phi_{2}(1-\xi) \cdots(6.14)
\end{aligned}
$$

\section{数 值 例}

J.H. Gaines と E. Volterra は Rayleigh-Ritz の方 法によって, double cone 形の Timoshenko beam の 固有振動について研究している $\left.{ }^{5}\right)$ ので, この例を借用す る。 $x=0$ で直径 $d_{1}$ をもち, $x=l$ で直径 $d_{0}\left(>d_{1}\right)$ を もつ円錐台形のビームを直径 $d_{0}$ の面で 2 つ接合してあ る double cone で, 両端が自由な固有振動を考える。 対称性によって半分だけをみればよいが，この際の境界 条件は，

$$
\begin{aligned}
& x=0 \text { で, } M=Q=0, \\
& x=l \text { で, } Q=\theta=0 .
\end{aligned}
$$

となる。

$x=l$ における断面積 および断面二次モーメントを $A_{0}, I_{0}$ とすれば，一般に $A(x), I(x)$ は，

$$
\begin{aligned}
& A(x)=A_{0}\left\{\frac{d_{1}}{d_{0}}+\left(1-\frac{d_{1}}{d_{0}}\right) \frac{x}{l}\right\}^{2} \\
& I(x)=I_{0}\left\{\frac{d_{1}}{d_{0}}+\left(1-\frac{d_{1}}{d_{0}}\right) \frac{x}{l}\right\}^{4}
\end{aligned}
$$

と表わされる。

求める固有値は $\Lambda$ :

$$
\Lambda^{2}=\frac{p^{2} \rho A_{0} l^{4}}{E I_{0}}
$$

とし $E / \kappa G=\mu$ は 2.89 と仮定する。パラメーターと しては $d_{1} / d_{0}$ と $l / d_{0}$ の 2 つをとり, 前者については 1.0 と 0.8 , 後者については $3.0,5.0,10.0$ の場合を 試算してみる。断面が円であるので $d_{0}=4 r_{0}$ となって いる。

\begin{tabular}{|c|c|c|c|}
\hline 表一5 & $\begin{array}{c}d_{1} / \boldsymbol{d} \\
\text { 固有 } \\
\Lambda^{2}=\end{array}$ & $\begin{array}{c}=1.0 \\
\Lambda \text { の } \\
b^{2} A_{0} l^{4} \\
E I_{0}\end{array}$ & $\begin{array}{l}\text { 对する } \\
\text { 值 }\end{array}$ \\
\hline \multirow{2}{*}{$l / d_{0}$} & モ & - & $r^{\circ}$ \\
\hline & 1 & 2 & 3 \\
\hline 3 & 5.235 & 22.93 & 45.16 \\
\hline 5 & 5.454 & 26.74 & 58.00 \\
\hline 10 & 5.557 & 29.20 & 68.91 \\
\hline${ }^{\infty}$ & 5.593 & 30.23 & 74.64 \\
\hline
\end{tabular}

最初に $d_{1} / d_{0}=1.0$ の場 合をとる。このときは解析 的な解が可能であるので, 比較のためにこの $A$ 值を みておこう（表一5）。次に 式 (6.11) の変形関数を用 いて有限要素法で計算す る。エレメントの数を 2 個

\begin{tabular}{|c|c|c|c|c|c|c|c|}
\hline \multirow{4}{*}{$l / d_{0}$} & & \multicolumn{3}{|c|}{$€$} & \multicolumn{3}{|c|}{${ }^{*}$} \\
\hline & & \multicolumn{2}{|c|}{1} & \multicolumn{2}{|c|}{2} & \multicolumn{2}{|c|}{3} \\
\hline & & \multicolumn{2}{|r|}{$I$} & $v$ & ข & 数 & \\
\hline & & 2 & 4 & 2 & 4 & 2 & 4 \\
\hline \multirow{3}{*}{3} & $A$ & 5.260 & 5.239 & 23.86 & 23.37 & 62.57 & 48.40 \\
\hline & $\phi$ & 0.1 & 0.0 & 2.9 & 0.7 & 19.6 & 2.9 \\
\hline & $e$ & 0.6 & 0.1 & 4.5 & 2.2 & 39.5 & 7.9 \\
\hline \multirow{3}{*}{5} & $A$ & 5.468 & 5.455 & 27.36 & 27.03 & 76.26 & 60.78 \\
\hline & $\phi$ & 0.1 & 0.0 & 1.4 & 0.3 & 10.5 & 1.7 \\
\hline & $e$ & 0.3 & 0.1 & 2.5 & 1.3 & 32.1 & 5.2 \\
\hline \multirow{3}{*}{10} & $A$ & 5.565 & 5.558 & 29.56 & 29.34 & 84.17 & 70.57 \\
\hline & $\phi$ & 0.0 & 0.0 & 0.4 & 0.1 & 3.2 & 0.6 \\
\hline & $e$ & 0.2 & 0.0 & 1.3 & 0.5 & 22.3 & 2.6 \\
\hline
\end{tabular}
および 4 個とした際の $\Lambda$ の值が表一6に示されてい る。モードは 3 次までとってある。近似の度合を表わす 量として $\phi$ を並記し，さらに解析的な値に対する誤差 $e \%$ む付してある。

モードが高くなるほど，また $/ / d_{0}$ が小さくなるほど， 誤差が大きくなる。 4 エレメント系で 3 次のモードまで
表一6 $d_{1} / d_{0}=1.0$ に対する固有值 $A$

$$
\Lambda^{2}=\frac{\rho p^{2} A_{0} l^{4}}{E I_{0}}
$$

計算すると, $l / d_{0}=5.0$ のときに $5.2 \%$ の誤差を生じる

\begin{tabular}{|c|c|c|c|c|c|c|c|}
\hline \multirow{4}{*}{$l / d_{0}$} & & \multicolumn{3}{|c|}{$モ$} & \multicolumn{3}{|c|}{ ド } \\
\hline & & \multicolumn{2}{|c|}{1} & \multicolumn{2}{|c|}{2} & \multicolumn{2}{|c|}{3} \\
\hline & & \multicolumn{2}{|r|}{$I$} & $v$ & ン $\quad$ r & \multicolumn{2}{|l|}{ 数 } \\
\hline & & 2 & 4 & 2 & 4 & 2 & 4 \\
\hline \multirow{3}{*}{4} & $\Lambda$ & 5.447 & 5.421 & 22.83 & 22.44 & 61.13 & 46.68 \\
\hline & $\phi$ & 0.1 & 0.0 & 2.6 & 0.6 & 18.8 & 2.7 \\
\hline & $e^{\prime}$ & 0.6 & 0.2 & 4.0 & 2.2 & 40.6 & 7.3 \\
\hline \multirow{3}{*}{5} & $A$ & 5.633 & 5.618 & 25.72 & 25.45 & 71.74 & 57.06 \\
\hline & $\phi$ & 0.1 & 0.0 & 1.2 & 0.3 & 9.3 & 1.5 \\
\hline & $e^{\prime}$ & 0.3 & 0.1 & 2.2 & 1.2 & 31.3 & 4.5 \\
\hline \multirow{3}{*}{10} & $\Lambda$ & 5.720 & 5.710 & 27.45 & 27.26 & 77.66 & 64.82 \\
\hline & $\phi$ & 0.0 & 0.0 & 0.3 & 0.1 & 2.7 & 0.5 \\
\hline & $e^{\prime}$ & 0.2 & 0.0 & 1.2 & 0.5 & 20.5 & 1.9 \\
\hline
\end{tabular}
が, $l / d_{0}=10.0$ となると $2.6 \%$ の誤差となって著しく 小さくなる。 $l / d_{0} \rightarrow \infty$ とみなされる通常のビームでは誤 差は非常に小さいわけである。これに対して $l / d_{0}=3.0$ では 4 エレメント系で 7.9\% の誤差をむち, さらにエ レメントを増すことも必要になる。誤差の大きさはおお

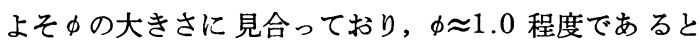
誤差は $5 \%$ 程度以下である。

表一 $7 d_{1} / d_{0}=0.8$ に対する固有值 $\Lambda$

$$
\Lambda^{2}=\frac{\rho p^{2} A_{0} l^{4}}{E I_{0}}
$$

$e^{\prime}=(\Lambda$-上限値 $) \times 100 /$ 上限值 ${ }^{(*)}$

(*) 論文)による

表一7 は $d_{1} / d_{0}=0.8$ の場合について同様な演算を行 なった結果である。ここの誤差 $e^{\prime} \%$ は Gaines and Volterra による上限值に対してとってある。同氏の計 算法はビーム全体を 1 区間として 7 次までの多項式を 14 個試算する Rayleigh-Ritz 法である。この方法によ ってまず上限值を求め, ついで上限值を用いて下限值を 評価している。同氏も指摘しているように，この下限值 はまだ十分でなく，上限值が相対的に真值に近いと思わ 
れるので, 上述のように表では上限值をとって, 本論の 方法の結果と比較をすることにした。

表一7 の全体的な傾向は 表一6 と非常によく似てお り，ここでも申の大きさによって近似の程度を評価する ことができる。

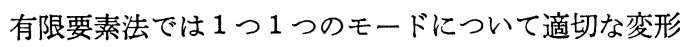
関数を探すのではなく, 1 つの変形関数で数次のモード をカバーすることになるが, 以上の考察より，ここで適 用されている有限要素法の手法は良い近似を与えている といえよう。

\section{7.むすび}

骨組構造の構成分としてのビームの固有振動を算出す るのに, 有限要素的な手法を用い, 微分方程式の形のま まで近似解を求める試算を行なった。この手法では変形 関数は断面定数から定められ，方法上の誤差を含まない 形での静力学的な変形法の関係式もこの変形関数で表現 することができる。

また, 計算結果の近似の度合が比較的よく評価でき る。このことはエレメントの大きさの選定に役立つとと もに, 他の形の変形関数を探す一つの手がかりともな る。Timoshenko beam の解析例はそのような一つの例 である。適切な変形関数が探せるかどうかは，この手法
では微分方程式の形式にかかっているので, 応用上に現 われる他の型について研究することは今後の課題とした い。

本論の研究について猪瀬寧雄博士（日建コンサルタン 卜社長）から助言をいただいたこと，さらに，土木学会 論文集編集委員会第 1 部門の查読委員の諸先生にご教示 を受けたことを付記して，感謝の意を表する。

\section{参考文 献}

1) Pian, T.H.H. and Tong, P. : Basis of Finite Element Methods for Solid Continua, Int. J. Num. Meth. Engng., 1.1 (1969).

2) Gallagher, R.H. and Lee, C.H. : Matrix Dynamic and Instability Analysis with non-uniform Elements, Int. J. Num. Meth. Engng., 2.2 (1970).

3) Tong, P. : New Displacement Hybrid Finite Element Models for Solid Continua, Int. J. Num. Meth. Engng., 1.2 (1970).

4) Ramden, J.N. and Stoker, J.R. : Mass Condensation: a Semi-automatic Method for Reducing the Size of Vibrating Problems, Int. J. Num. Meth. Engng., 4.1 (1969).

5) Gaines, J.H. and Volterra, E. : Upper and Lower Frequencies of Tapered Beams, Journal of the Engineering Mechanics Division, ASCE, Vol. 94, No. EM 2, Apr. 1968.

6) Bellman, R. : Methods of Nonlinear Analysis, Academic Press, 1970.

(1971.9.28 - 受付) 